\title{
62. 扁桃の酸化還元系物質について
}

\author{
斉藤 英雄・野田寛
}

扁桃の機能を解明する目的で, 当教室では免疫学的に は種々の細菌・ウィルスによる抗体産生能，醅素学的に は LDH 活性及びその Isozyme-Pattern を扁挑各組織 について檢討してきた，そこで我々は，それらの免疫機 構並びに物質代謝と直接間接に重要な関係を持つVit.

C, 鉄及び Glutathione など一連の酸化還元物質の消長 について检討を加えた，殊に Vit. C は口蓋扁挑の種タ の疾患時に変化のあることが報告されているので，それ と密接な関俰にある鉄及び Glutathione にいかなる 变 化があるか，扁桃各組織間の相互関係について検討した 成瞔を報告した。

\section{〔測定方法〕}

Vit. C は Dinitrophenol 法により，その総量及び唒 化型量を測定し，還元型量を計算で求めた．

鉄は Bathophenanthroline 法で，その総量を，また。 O-Phenanthroline 法で，その非へム鉄量を求めた，総 SH 量は Dithiobis-nitrobenzoate 法で比色定量し, Glutathione の真の酸化・還元型量は，我々の改良考案 した酻案的測定法により各々求めた。

\section{〔実 験 成 鈢〕}

扇桃各組織の Vit. C 量を各䑏器のそれと比較し一括 した成績が园 1 で，碉桃各組織閒では，舌根扁桃の総量
は少いが，各組織とも還元型がその大部分を占め，酸化 型は著しく少ない，しかし扁桃全体としてみると，各臓 器に比較して高い值を示す。

同樣に各扁桃の鉄量を各臓器と共に比較した成績が図 2 で，その総鉄量は各臓器䦌では少ない万であるが，各 扁桃間では著しい差はない，しかし，へム鉄/非へム鉄 比は咽頭扁桃と他の二者の間で著しく相異し，口蓋・舌 根雨扁桃の非へム鉄は非常に少ない。

SH 量についてみた成續が図るで，扁桃は各臓器中で 含量が少ないが，各扁桃間には著しい差はない，酵素的 に測定した Glutathione 量を一括したのが図4で，還 元型がその大゙部分を占める，しかし，その還元型 Glutathione (GSH) 量は，総 SH の約55\%で，比色法で求 められる SH の中には，GSH 以外のるのが相当含ま れていることがわかった。

\section{〔結〔論〕}

扁桃各組織内の酸化還元物質中，Vit，C を除き，SH 及び鉄法その総量に著しい差はないが，それ等を構成す

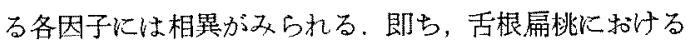
Vit. C 量の少ないこと、へム鉄/非へム鉄・比が，口 蓋・舌根扁桃々咽頭扁桃と翼ること，及び GSH が総 SH の約半分に滆な゙ないことなど，特に注目される， 
图 1 薪桃のビタミンC含有量 (DNP 法)

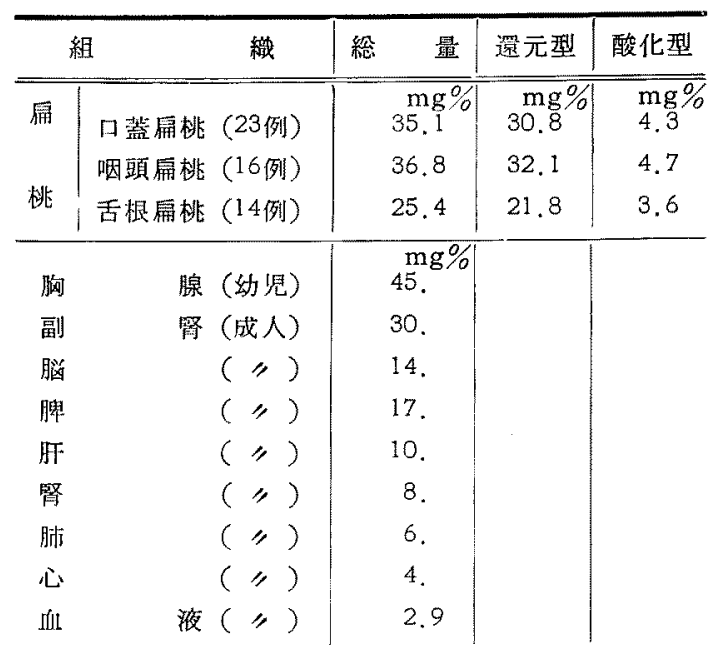

图 3 扁桃の総 $\mathrm{SH}$ 量 (DTNB 法, GSH 基準)

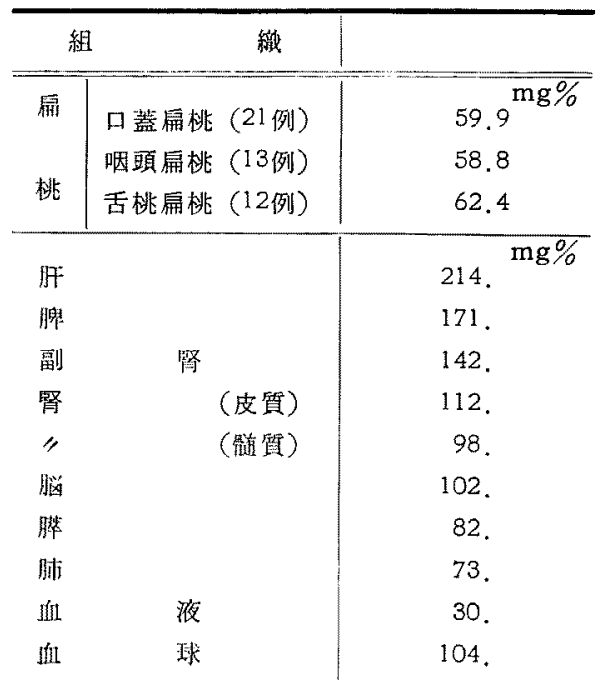

图 2 廍桃心鉄含有量

総 鉄 量一Bathophenanthroline 法 非へ公鉄量一O-Phenanthroline 法

\begin{tabular}{|c|c|c|c|c|}
\hline \multicolumn{2}{|c|}{ 組 } & 縒 鉄 量 & へ公鉄量 & $\begin{array}{l}\text { 非へA } \\
\text { 敛量 }\end{array}$ \\
\hline \multirow[t]{2}{*}{ 滆 } & 口蓋扁桃（15例） & $\underset{5.30}{\mathrm{mg}} \%$ & $\begin{array}{l}\mathrm{mg} \% \\
3.61\end{array}$ & $\overline{\mathrm{mg}} \%$ \\
\hline & 咽頭扁桃（11例） & 5.25 & 2.25 & $3 . \infty$ \\
\hline 桃 & 舌根屚桃 ( 7 例) & 5.21 & 3.81 & 1.40 \\
\hline 嘷 & 清（人） & $\mathrm{mg}_{0.12} \%$ & $\mathrm{mg} \%$ & $\mathrm{mg} \%$ \\
\hline 肝 & （海埧） & 16.4 & 2.6 & 13.8 \\
\hline 脾 & $(1)$, & 108.6 & 9.4 & 99.2 \\
\hline 脑 & $(")$ & 11.0 & 3.0 & 8.0 \\
\hline 贯 & $(1)$, & 9.0 & 3.3 & 5.7 \\
\hline$心$ & 符 ( " " ) & 6.7 & 2.1 & 4.6 \\
\hline fit & 稙 (" ) & 20.4 & & \\
\hline 血 & 液 ( " ( ) & 29.5 & & \\
\hline Ifll & 清 ( " ) & 0.14 & & \\
\hline
\end{tabular}

图 4 扁桃及び各臓器に拈けるGlutathione と繶 $\mathrm{SH}$ との閔係

\begin{tabular}{|c|c|c|c|c|c|}
\hline 組 & \multicolumn{2}{|c|}{ 織 } & $\mathrm{GSH}$ & G S-S G & 総 S H \\
\hline \multicolumn{3}{|c|}{ 口蓋扁桃（１ 例） } & $\underset{39.6}{\mathrm{mg} \%}$ & $\begin{array}{l}\mathrm{mg} \% \\
7.2\end{array}$ & $\mathrm{mg} \%$ \\
\hline 脾 & (白䦠 & 匹) & 94.9 & 4.1 & 133.5 \\
\hline 胃 & C " & ) & 89.3 & 1.2 & 212.8 \\
\hline 婜 & ( " " & ) & 85.7 & 5.7 & 150,6 \\
\hline 肝 & ( & ) & 77.7 & 1.8 & 106.2 \\
\hline 腸 & ( & ) & 55.3 & 3.6 & 90.3 \\
\hline 䐉 & ( & ) & 55.2 & 5.3 & 74.1 \\
\hline 心 & $C$ & ) & 45.2 & 12.5 & 63.0 \\
\hline 骨格筋 & $C$ & ) & 31.8 & 5.6 & 42.3 \\
\hline 肺 & ( & ) & 27.8 & 0.7 & 58.1 \\
\hline 血 液 & ( & ) & 23.4 & 5.6 & 67.0 \\
\hline
\end{tabular}

